\title{
Fine-scale responses of phytoplankton to freshwater influx in a tropical monsoonal estuary following the onset of southwest monsoon
}

\author{
Suraksha M Pednekar ${ }^{1}$, S G Prabhu Matondkar ${ }^{1, *}$, Helga Do R Gomes $^{2}$, \\ JoAquim I Goes ${ }^{2}$, Sushma Parab ${ }^{1}$ and Vijaya Kerkar ${ }^{3}$ \\ ${ }^{1}$ National Institute of Oceanography, Dona Paula, Goa 403 004, India. \\ ${ }^{2}$ Bigelow Laboratory for Ocean Sciences, West Boothbay Harbor, Maine 04575, USA. \\ ${ }^{3}$ Department of Botany, Goa University, Taleigao, Goa 403 004, India. \\ *e-mail: sgpm@nio.org
}

In May of 2007, a study was initiated by the National Institute of Oceanography (NIO), Goa, India, to investigate the influence of monsoonal rainfall on hydrographic conditions in the Mandovi River of India. The study was undertaken at a location $\sim 2 \mathrm{~km}$ upstream of the mouth of this estuary. During the premonsoon (PreM) in May, when circulation in the estuary was dominated by tidal activity, phytoplankton communities in the high saline (35-37 psu) waters at the study site were largely made up of the coastal neritic species Fragilaria oceanica, Ditylum brightwellii and Trichodesmium erythraeum. During the later part of the intermonsoon (InterM) phase, an abrupt decline in salinity led to a surge in phytoplankton biomass (Chlorophyll $a \sim 14 \mathrm{mg} \mathrm{m}^{-3}$ ), of a population that was dominated by Thalassiosira eccentricus. As the southwest monsoon (SWM) progressed and the estuary freshened salinity and Chlorophyll a (Chl a) concentrations decreased during the MoN, Skeletonema costatum established itself as the dominant form. Despite the low biomass (Chl $a<2 \mathrm{mg} \mathrm{m}^{-3}$ ), the phytoplankton community of the MoN was the most diverse of the entire study. During the postmonsoon (PostM), the increase in salinity was marked by a surge in dinoflagellate populations comprising of Ceratium furca, Akashiwo sanguinea, and Pyrophacus horologium.

\section{Introduction}

A unique feature of the rivers along the west coast of India is the phenomenal tides that they are subjected to (Shetye et al 2007). As a consequence, these rivers experience large influxes of seawater which have a significant impact on circulation, salinity (Shetye et al 2007; Vijith et al 2009) as well as water column turbidity caused by the disturbance of bottom sediments (Devassy and Goes 1988). On account of this free mixing of coastal seawater with freshwater, these rivers represent a stressing habitat for phytoplankton growth defined by large fluctuations in salinity, nutrients, light and temperature (Devassy and Goes 1988).

On an average, Goa receives $80 \%$ of its total rainfall (3000 mm) from June to August. It is during this period, that the Mandovi and the Zuari become completely freshwater dominated (Shetye et al 2007; Vijith et al 2009). Freshwater outflow from these two estuaries is strongly regulated by tides which are semi-diurnal in nature and whose influence is most prominent at the downstream end of these rivers (Shetye et al 2007). Spikes of

Keywords. Chlorophyll $a$; rainfall; phytoplankton; species diversity; salinity; tide. 
freshwater influx into the estuary are always associated with steep increases in inorganic nutrients; these being mostly from excess fertilizer run-off from the surrounding rice fields (DeSousa et al 1981). In one of the most comprehensive studies of phytoplankton in these two estuaries, Devassy and Goes (1988) showed that the distribution, abundance and productivity of phytoplankton were strongly regulated by salinity and nutrients. Their findings were consistent with laboratory cultures of tropical estuarine phytoplankton by Qasim et al (1972) who demonstrated that moderately low salinities supported a greater phytoplankton growth when inorganic nutrients were not constraining.

Devassy and Goes (1988) observed that the Mandovi unlike the river Zuari, retained typical estuarine conditions for most part of the year and that it sustained a very high phytoplankton population during the PostM season. At the peak of the MoN season, phytoplankton biomass and diversity were at their lowest (Devassy and Goes 1988). Although the studies by Devassy and Goes (1988) represent the first account of phytoplankton diversity in the Mandovi and Zuari rivers, the inferences of monsoon-related changes in phytoplankton biomass and community succession patterns were based on monthly observations and so yielded only broad patterns of change in phytoplankton.

Present findings revealed the evolution of phytoplankton communities and their biomass as the southwest monsoon rainfall progressed and fresh- water influx changed conditions in the Mandovi estuary. The datasets revealed rapid changes in near-surface salinity in the Mandovi river following the onset of the SWM and progress of the rainy season (Suprit and Shankar 2008). The present study represents the first detailed investigation on the effects of freshwater discharge on phytoplankton populations in a tropical monsoon-influenced estuary.

\section{Materials and methods}

\subsection{Sampling site and sampling protocols}

The Mandovi river is a tropical estuary located along the west coast of India between $15^{\circ} 21^{\prime}$ $15^{\circ} 31^{\prime} \mathrm{N}$ and $73^{\circ} 45^{\prime}-73^{\circ} 49^{\prime} \mathrm{E}$. Together with the Zuari river and the Cumbarjua canal, it forms the major estuarine system of the State of Goa (figure 1). Like all the major rivers that run across the coastal plains of the west coast of India, the Mandovi and the Zuari rivers are important conduits for freshwater run-off from the slopes of the Sayhadri hills, through the coastal plains of the west coast of India, into the Arabian Sea. Freshwater run-off is greatest during the southwest monsoon (SWM, summer), usually from the end of June to early September, when most rivers along the west coast of India become freshwater dominated (Vijith et al 2009). Sampling in the Mandovi river commenced on 23 May 2007, well before the predicted start

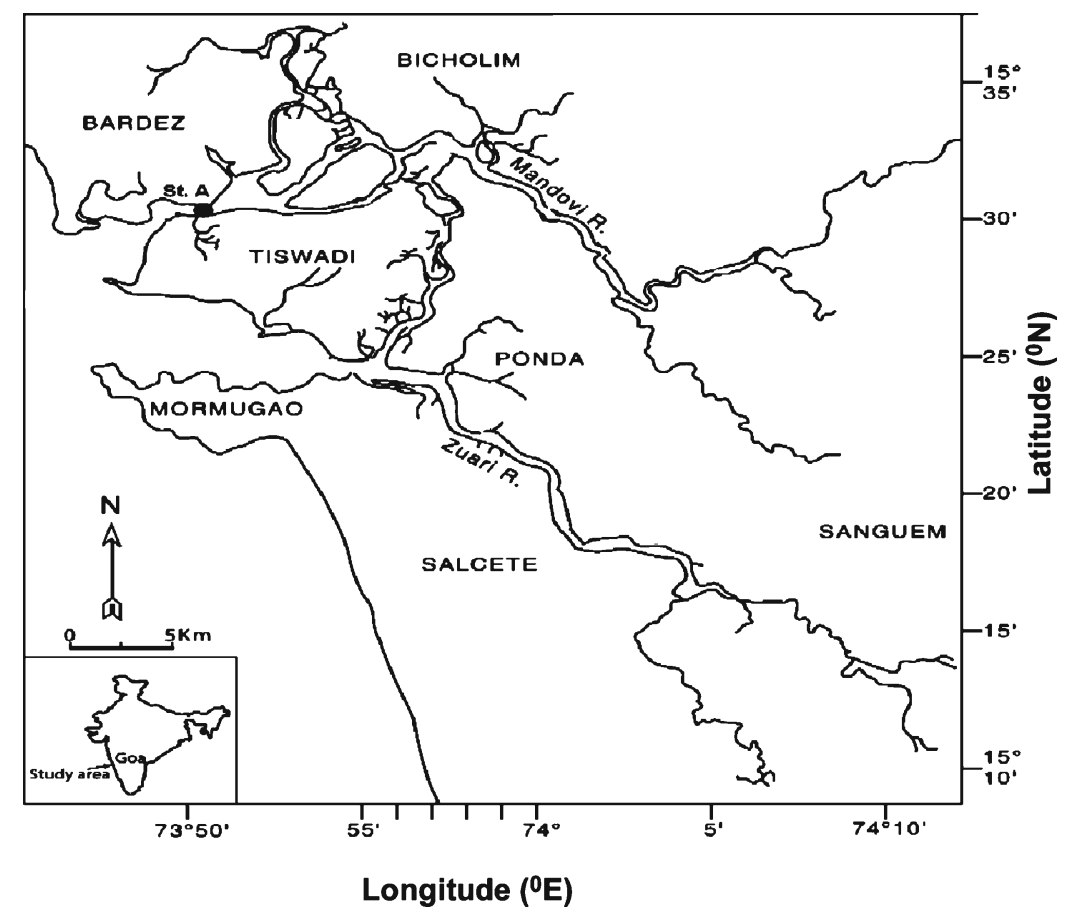

Figure 1. Map showing sampling station (St. A) in Mandovi estuary. 
of the SWM of 2007 by the India Meteorological Department. Surface water samples were collected daily from a location $\sim 2 \mathrm{~km}$ upstream of the mouth of the Mandovi estuary (figure 1), from 23 May to 30 November 2007 encompassing the premonsoon (PreM) from JD 143-JD 147 (23 May-27 May 2007), intermonsoon (InterM) from 28 May23 June 2007, i.e., JD 148-JD 174, monsoon (MoN) from JD 175-272 (24 June-29 September 2007) and postmonsoon (PostM) from JD 273-JD 334 (30 September-30 November 2007). Since the collection of samples was on a daily basis, for better presentation and interpretation of data, Julian day is preferred to the ordinal calendar. This site was chosen for two reasons: first, because of its easy access as NIO's coastal research vessel $C R V$ Sagar Shukti which was anchored at the site during the entire study period, and second, because of the large salinity range $(37-0 \mathrm{psu})$ that the site experiences following the onset of the monsoon season (Shetye et al 2007). At the highest high-tide, the maximum depth of this location is about $6 \mathrm{~m}$. During most part of our study, the water column was turbid and well mixed (Suprit and Shankar 2008). Sampling for phytoplankton biomass and cell counts was restricted to the surface and collected at exactly 11:00 h everyday. Samples were then immediately transported under cold and dark conditions for further processing at the NIO. Due to logistical constraints, samples could not be collected on few days (total five days only) like 25 May, 30 Sepember 2007 and from 1-3 October 2007.

Tidal heights were recorded by means of a tidepole described in more detail in Sundar and Shetye (2005). Salinity was measured with a 'Salinometer' (Atago S/Mill ${ }^{\circledR}$, Japan, Salinity range 0 100 psu, resolution 1 psu between $10^{\circ}$ and $20^{\circ} \mathrm{C}$ ). Nitrate was estimated using the method outlined in Parsons and Strickland (1963). From the historical data available on nitrate it is clear that abrupt change in the nitrate concentration takes place only during the MoN period. In the PostM, variations in the nitrate concentration is less. Hence, in the present study we restricted our daily analyses to the period between the PreM (May) and early MoN (June) and further monitored fortnightly in the Mandovi estuary.

Samples for cell counts and phytoplankton taxonomy were collected in duplicate in $500 \mathrm{ml}$ plastic bottles and fixed with a few drops of Lugol's iodine. Prior to microscopic analysis, samples were concentrated to $5-10 \mathrm{ml}$ by carefully siphoning with a tube covered with a $10 \mu \mathrm{m}$ Nytex filter on one end. Sample concentrates were then carefully transferred to a 1 ml-capacity Sedgwick-Rafter and counted using an Olympus ${ }^{\circledR}$ Inverted microscope (Model IX 50) at 200× magnification. Phytoplankton cell identification was based on standard taxonomic keys (Tomas 1997). Results (averages of duplicate counts), are expressed as cell numbers $\times$ $10^{4} \mathrm{~L}^{-1}$. Phytoplankton biomass estimated as Chl $a$ was measured by filtering $500 \mathrm{ml}$ water samples on to $47 \mathrm{~mm}$ glass fiber filters (Whatman ${ }^{\circledR}$ $\mathrm{GF} / \mathrm{F}$ ), which were then extracted overnight in $10 \mathrm{ml}$ of $90 \%$ acetone under cold and dark conditions. Pigment extracts were then filtered through PTFE $(0.2 \mu \mathrm{m})$ filters for removal of phytoplankton and $\mathrm{GF} / \mathrm{F}$ filter debris. Chl $a$ was estimated in duplicate using High Pressure Liquid Chromatography (Agilent ${ }^{\circledR} 1100$ series) where pigment separation was done in a $\mathrm{C}$-18 reverse-phase column using the eluent gradient program of Wright et al (1991) and Parab et al (2006), using DHI, Denmark pigment standards.

\subsection{Statistical methods for data analysis}

Statistical treatment of the data was undertaken using software PRIMER 5.2.8 (Clarke and Warwick 1994). Species diversity $\left(H^{\prime}\right)$ was calculated using the following equation,

$$
H^{\prime}=-\sum\left(P_{i} \log _{2}\left(P_{i}\right)\right),
$$

where $P_{i}=n_{i} / n$ (proportion of the sample belonging to $i$ th species. $S$ is the number of species and $N$ is the total number of individuals of all the species in a sample) by Shannon and Weaver (1963).

Phytoplankton species associations were examined by hierarchical cluster analysis using the Bray-Curtis similarity index as an estimate of similarity among species.

\section{Results}

\subsection{Tides}

Water level heights (shown in figure 2) ranged from 0.17 to $2.27 \mathrm{~m}$. In both the Mandovi and Zuari rivers, water level heights are not determined by tides alone, but by variations in run-off which can be particularly high during the SWM (Shetye et al 2007). At our study site, the impact of rainfall and freshwater run-off on the tide-pole measurements was not particularly discernible, as no distinct differences in water level heights were seen between dry and rainy periods (figure 2). Given that the impact of freshwater run-off decreases downstream as the cross-section of the estuary becomes wider (Shetye et al 2007), this is not an unusual observation.

\subsection{Rainfall and salinity}

The pattern of salinity variation with respect to rainfall across the monsoon period is shown in figure 3 . 


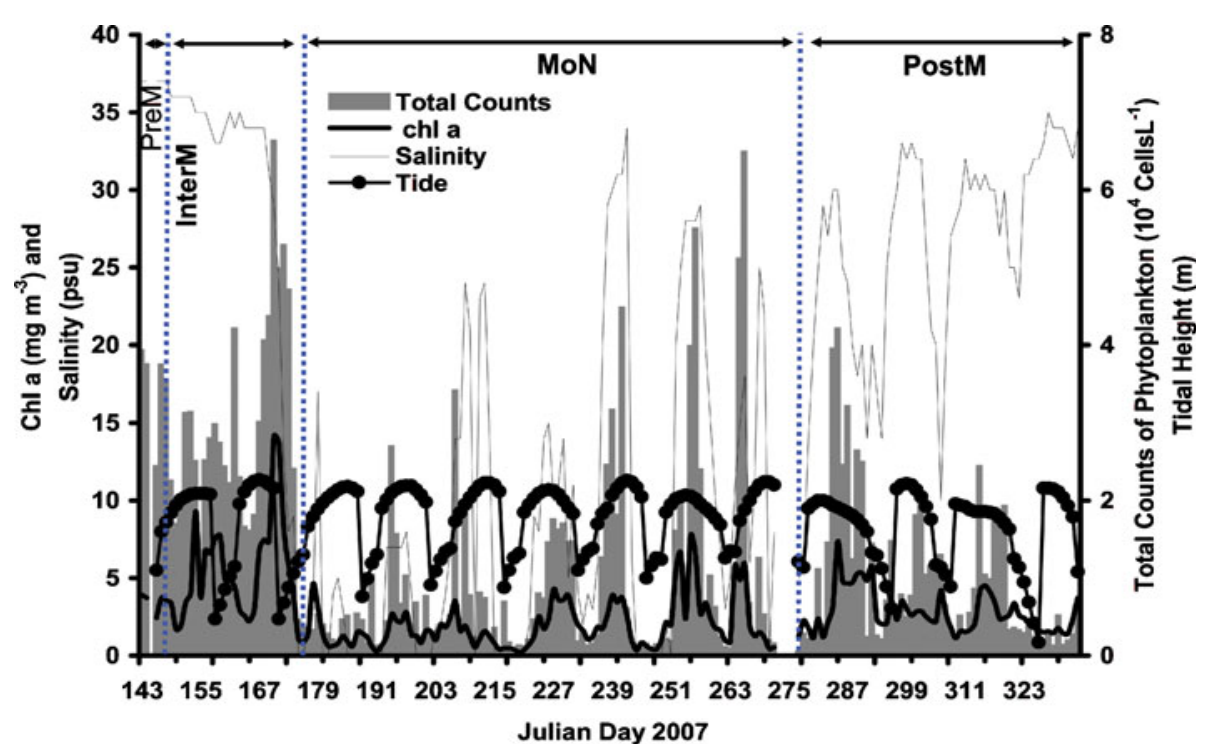

Figure 2. Variation in Chl $a$, salinity, total phytoplankton counts and tide in Mandovi estuary, where 143-147 is PreM, 148-174 is InterM, 175-272 is MoN and 273-334 is PostM.

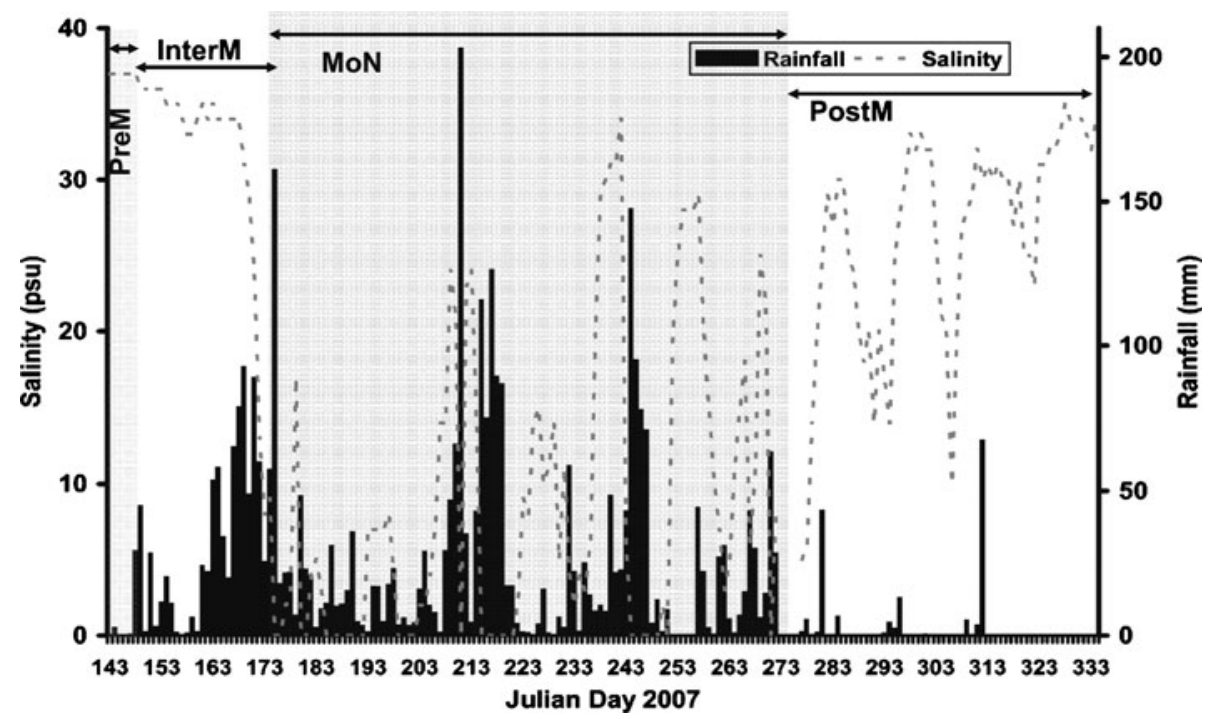

Figure 3. Variation in salinity and rainfall in Mandovi estuary, where 143-147 is PreM, 148-174 is InterM, 175-272 is MoN and $273-334$ is PostM.

They are inversely related. During PreM phase from JD 143-147 when sampling began, salinity was very high, with levels averaging $37 \pm 2$ psu. The commencement of the rainy season in the last week of May 2007 (JD 148-174, InterM phase) was characterized by sporadic showers which caused salinity levels to drop to $35 \pm 2$ psu. By 18 June 2007 (JD 169), when the rainfall had increased, salinity values declined rapidly and by 26 June (JD 177), intense rainfall and extensive run-off from the surrounding areas had lowered salinity within the estuary to almost freshwater conditions (0 psu). This MoN phase (JD 175-272) witnessed large fluctuations in rainfall, wherein short spells of heavy rainfall were interspersed with extended periods of sporadic showers. The wettest periods were between JD 162 and JD 177, JD 208 and JD 221, and JD 230 and JD 249 (figure 3). These periods of heavy rainfall corresponded to dramatic decreases in salinity in the estuary. The highest rainfall of $203 \mathrm{~mm}$ was recorded on JD 211 (30 July 2007), causing salinity levels to reach almost $0 \mathrm{psu}$ in the Mandovi estuary. During the MoN phase, there were occasions when salinity levels rose to $\sim 24 \mathrm{psu}$ following a prolonged period of low rainfall. By the first week of October (PostM 
phase), rainfall had reduced to occasional and sporadic showers and salinity values began rising to between 3 and 7 psu.

\subsection{Nitrate}

Nitrate variation across the monsoon period in the Mandovi estuary is explained in figure 4 . Here the measurements are available for the period from PreM to early MoN between JD 143 and JD 177. From the figure it is clear that nitrate is inversely proportional to salinity, which we wanted to establish during the monsoon phase. Nitrate concentrations were $<1 \mu \mathrm{M}$ during the PreM phase, but slowly began to increase following the onset of the SWM. By the middle of June, nitrate concentrations had increased to $\sim 4 \mu \mathrm{M}$ and rose steadily thereafter. By 21 June (JD 172) nitrate concentrations were as high as $20 \mu \mathrm{M}$ reaching $26 \mu \mathrm{M}$ on 25 June (JD 176). Further fortnightly observations of that particular site during PostM showed not much fluctuation in the nitrate level. Nitrate concentration varied between 1.05 and $9.47 \mu \mathrm{M}$ as seen in figure 4.

\subsection{Phytoplankton biomass, groups, genera and species}

Phytoplankton biomass measured as Chl a ranged from $1.7-14.2 \mathrm{mg} \mathrm{m}^{-3}$ and as cell counts, from 0.09 to $6.63 \times 10^{4}$ cells $\mathrm{L}^{-1}$ (figure 2 ). Of the four phases of the monsoon, the highest concentrations of $\mathrm{Chl} a$ $\left(14.2 \mathrm{mg} \mathrm{m}^{-3}\right)$ and the highest microscopic counts of phytoplankton $\left(6.63 \times 10^{4} \mathrm{~L}^{-1}\right)$ were recorded during the InterM phase (figure 2), where Chl $a$ concentrations averaged $5.6 \mathrm{mg} \mathrm{m}^{-3}\left( \pm 3.3 \mathrm{mg} \mathrm{m}^{-3}\right.$, $n=27)$ and cell counts $3.0 \times 10^{4}$ cells L ${ }^{-1}( \pm 1.3 \times$ $10^{4}$ cells $\left.\mathrm{L}^{-1}, n=27\right)$. The InterM was characterized by three peaks of Chl $a$, the largest of which was $>6 \mathrm{mg} \mathrm{m}^{-3}$. During the PreM phase, average Chl $a$ concentrations were $3.5 \mathrm{mg} \mathrm{m}^{-3}( \pm 0.5 \mathrm{mg}$ $\left.\mathrm{m}^{-3}, n=4\right)$ and $3.4 \times 10^{4}$ cells $\mathrm{L}^{-1}\left( \pm 0.8 \times 10^{4}\right.$ cells $\mathrm{L}^{-1}, n=4$ ), respectively. In contrast, during the MoN phase, Chl a concentrations and cell counts were the lowest of the four phases averaging $2.0 \mathrm{mg} \mathrm{m}^{-3}\left( \pm 1.6 \mathrm{mg} \mathrm{m}^{-3}, n=98\right)$ and $0.9 \times 10^{4}$ cells $\mathrm{L}^{-1}\left( \pm 0.88 \times 10^{4}\right.$ cells $\left.\mathrm{L}^{-1}, n=98\right)$. During the early part of MoN phase, Chl $a$ concentrations declined to their lowest $\left(<2 \mathrm{mg} \mathrm{m}^{-3}\right)$ of the entire sampling period, but increased to $7.7 \mathrm{mg} \mathrm{m}^{-3}$ as the rainy season approached its end. Phytoplankton counts were also low during the early $\mathrm{MoN}$ phase $\left(<1 \times 10^{4}\right.$ cells $\left.\mathrm{L}^{-1}\right)$ but increased to $\sim 6.6$ $\times 10^{4}$ cells $\mathrm{L}^{-1}$ during the late MoN phase. During the PostM phase (JD 276-JD 334), Chl $a$ concentrations $\left(2.8 \mathrm{mg} \mathrm{m}^{-3}, \mathrm{SD} \pm 1.3 \mathrm{mg} \mathrm{m}^{-3}, n=58\right)$ and cell counts $\left(1 \times 10^{4}\right.$ cells $\mathrm{L}^{-1}, \mathrm{SD} \pm 0.96 \times$ $10^{4}$ cells $\mathrm{L}^{-1}, n=58$ ) were higher than during the MoN phase.

Diatoms were the major taxonomic group accounting for between $71 \%$ and $97 \%$ of the total population over the sampling period (figure $5 \mathrm{a}$ ). The highest percentage of diatoms $(97 \%)$ was recorded during the PreM phase, whereas the minimum of $71 \%$ was observed during the PostM

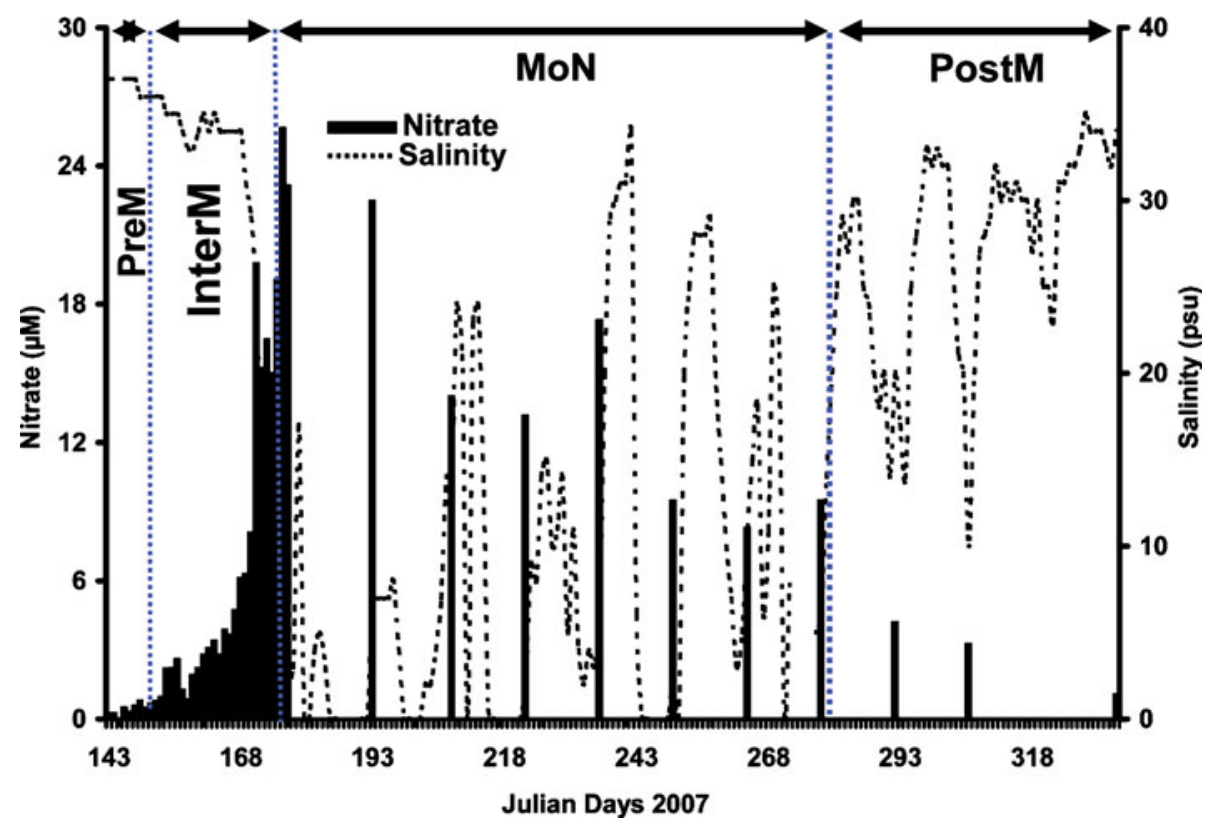

Figure 4. Variation in nitrate and salinity in Mandovi estuary, where 143-147 is PreM, 148-174 is InterM, 175-272 is MoN and 273-334 is PostM. 

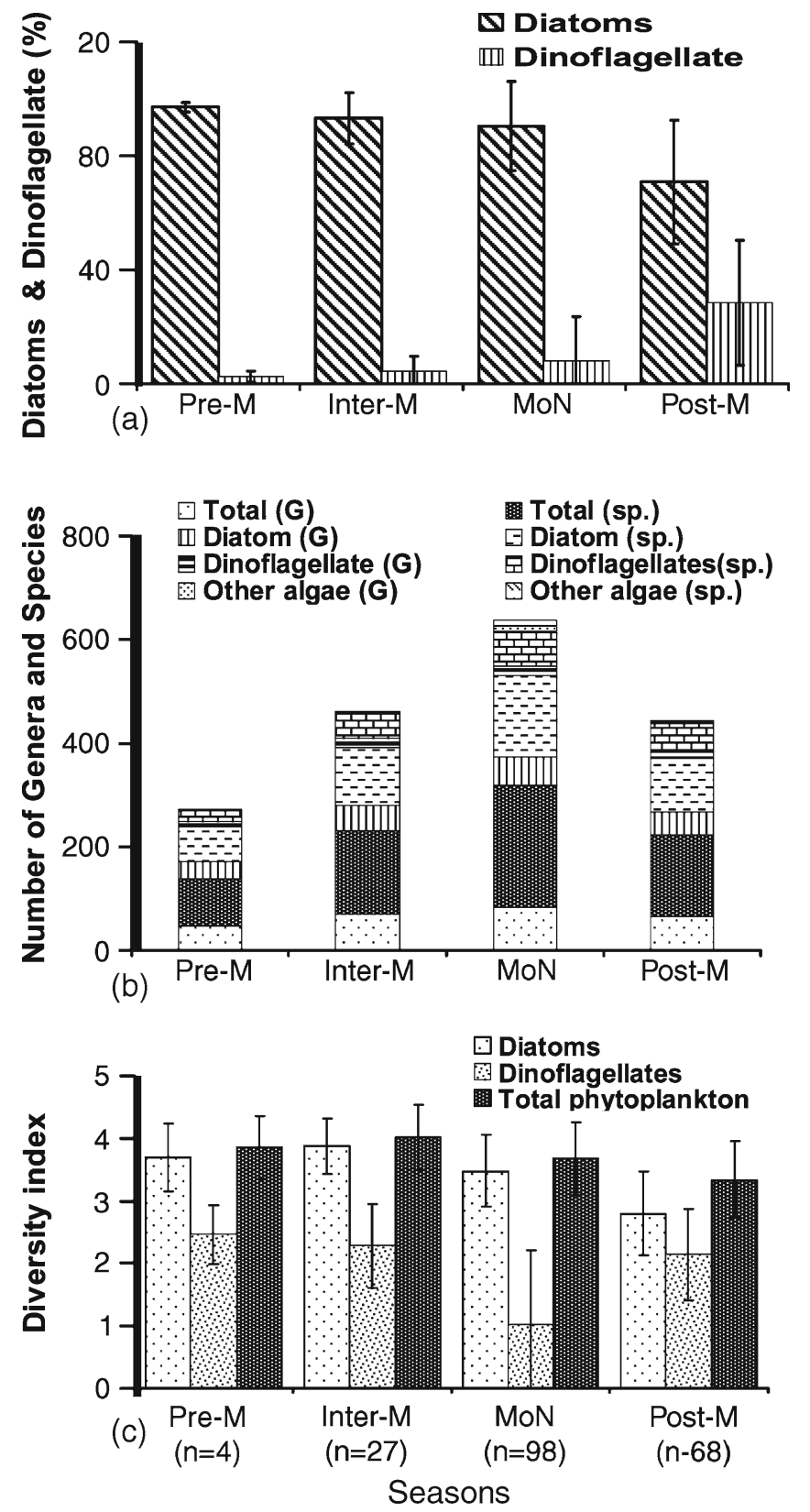

Figure 5. Seasonal variation in the Mandovi estuary (a) of the percentages of Diatom and Dinoflagellate populations, (b) of the total number of phytoplankton genera and the total number of phytoplankton species, and (c) of the diversity index of Diatom, Dinoflagellate and total phytoplankton population.

phase, as a group diatoms were unaffected by the low saline conditions during the peak MoN phase (figure 5a). Dinoflagellates, the second largest taxonomic group, varied from $2.6 \%-28.4 \%$ and displayed a definite seasonality (figure 5a), with the highest percentage being recorded during the PostM phase. The lowest percentage $(2.5 \%)$ of dinoflagellates was observed during the PreM phase. Other algae such as green algae and cyanobacteria constituted a small percentage of the population varying between $0.3 \%$ and $1.1 \%$.
The break-up of the total genera recorded during the four phases of this study is presented in figure 5(b). During the PreM phase, the total genera recorded were 47 , of which 34 were diatoms, 11 dinoflagellates and 2 comprised of other algae. The number of genera increased to 69 during the InterM phase with diatoms constituting 48, dinoflagellates 18. The highest number of 83 phytoplankton genera, was recorded during the MoN phase and were made up of diatoms (55), dinoflagellates (19) and other algae (9). During the PostM, the total number of genera recorded was 64 , with diatoms making up for 44, dinoflagellates 17 , and other algae 3.

Variations in the number of species recorded reflected the seasonality observed for genera (figure $5 \mathrm{~b}$ ). The highest number of species (235) were recorded during the MoN phase, with diatoms, dinoflagellates and other algae accounting for 157, 68 and 10 species, respectively (figure 5b). The second highest number of species was recorded during the InterM phase (162 species), with 112 species of diatoms, 46 species of dinoflagellates and 4 of other algae. This was followed by the PostM phase with a total of 158 species recorded, of which 104 were diatoms, 50 dinoflagellates and 4 other algae. The least number of species were recorded during the PreM phase (89 species), with diatoms constituting 67 of the total species, dinoflagellates 20 and other algae 2 species.

\subsection{Diversity of phytoplankton}

The large number of species recorded throughout this study contributed to the high species diversity indices between 3.34 and 4.02 with an average of 3.34. The average total phytoplankton diversity was highest (4.02) during InterM and the lowest (3.34), was during PostM. During MoN it was around 3.68 and in the PreM it was 3.85. In the case of diatoms, the highest diversity index of 3.87 was measured during InterM, in the $\mathrm{MoN}$ it was around 3.48, and in the PreM 3.70 while the lowest (2.8) was during the PostM phase. Dinoflagellates had the lowest diversity (1.03) during MoN, but varied only minimally during the other phases (figure 5c).

Figure 6 depicts the evolution of the major species in the Mandovi estuary with changes in species counts, Chl $a$ and salinity. Coscinodiscus nitidus was the most frequently observed species and occurred throughout the year, but at low concentrations during the PreM and PostM phases. Peaks in the Coscinodiscus nitidus counts were clearly associated with abrupt increases in salinity, observed first during the InterM and then during the MoN (figure 6a). Thalassiosira eccentricus was the dominant form during the PreM 

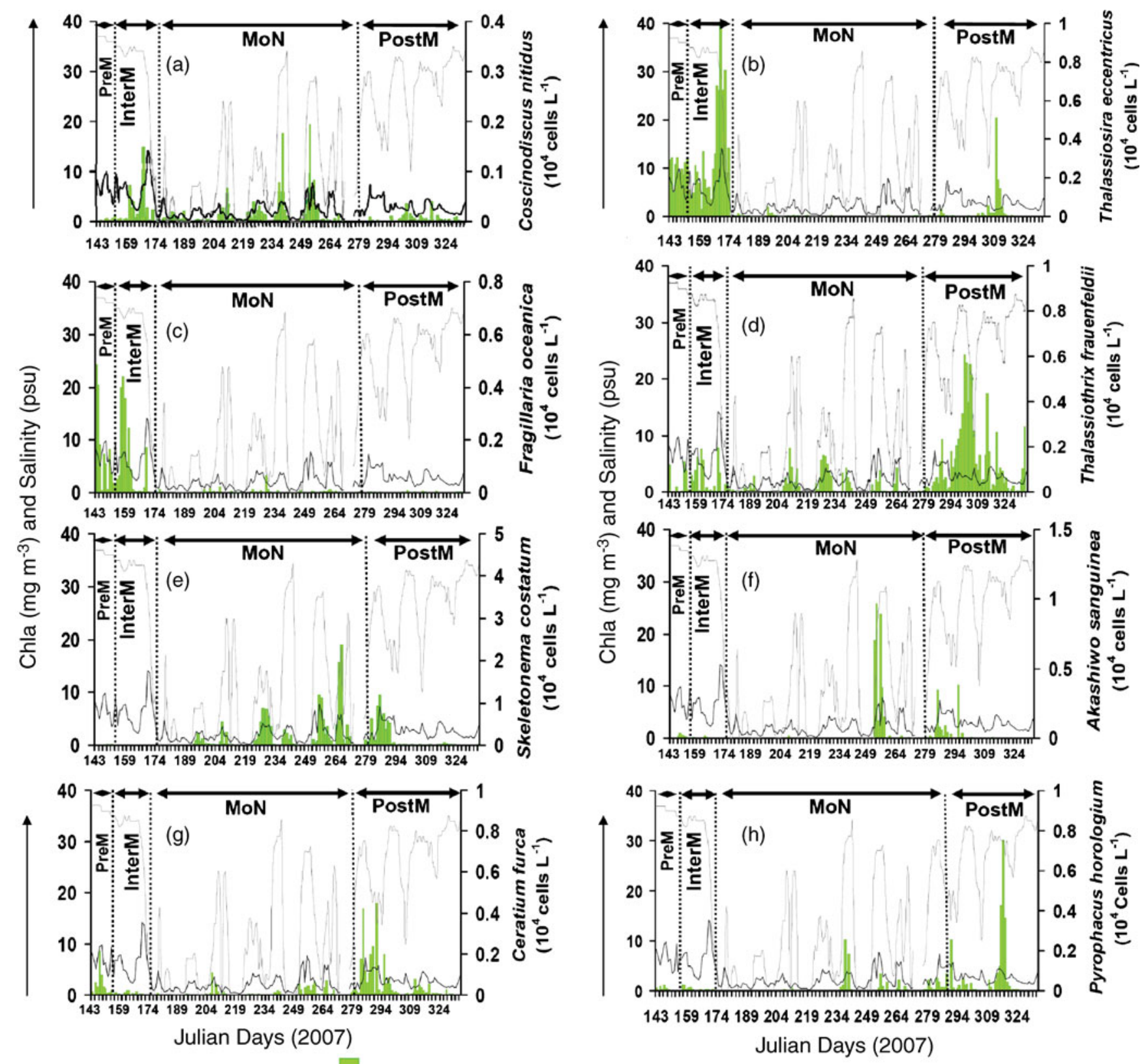

Species counts; - Chl a; - Salinity

Figure 6. Daily variation in relation to total Chl a concentrations and salinity in the Mandovi estuary (a) of the Coscinodiscus nitidus counts, (b) of the Thalassiosira eccentricus counts, (c) of the Fragilaria oceanica counts, (d) of the Thalassiothrix frauenfeldii counts, (e) of the Skeletonema costatum counts, (f) of the Akashiwo sanguinea counts, (g) of the Ceratium furca counts, and (h) of the Pyrophacus horologium counts.

and InterM (figure 6b), so was Fragilaria oceanica, an indication of their ability to thrive under high salinity (35-37 psu) waters (figure 6c). At other times of the year, these species were present in low numbers. Populations of Thalassiothrix frauenfeldii were highest when salinity values increased during the PostM (figure 6d). This species was also present in smaller numbers during the PreM and MoN indicating its ability to tolerate a wide range of salinities. Twice during the course of this study, on JD 147 (PreM) and JD 172 (InterM), Trichodesmium erythraeum was observed in large numbers (no. of trichomes $>1 \times 10^{4}$ cells $\mathrm{L}^{-1}$ ). The appearance of this diazotroph, Trichodesmium erythraeum and the coastal neritic diatom Fragilaria oceanica in the Mandovi estuary is surprising as they have frequently been observed in the offshore region. One of the most abundant form during the MoN and early PostM was the euryhaline chain forming diatom Skeletonema costatum with cell 
numbers at times reaching in excess of $2 \times 10^{4}$ cells $\mathrm{L}^{-1}$ (figure 6e).

The period towards the end of the MoN and the transition into the PostM marked the appearance of dinoflagellates. Among the dominant forms were Akashiwo sanguinea (figure 6f), Ceratium furca (figure 6g) and Pyrophacus horologium (figure 6h). Ceratium furca was present throughout the study except during the early and peak MoN when it appeared sporadically. Scrippsiella trochoidea was another species that was present in large numbers during PostM period. Except for a small spike in counts of this species towards the end of the MoN, this species was not seen during the other phases.

A cluster analysis of all the phytoplankton based on Bray Curtis similarity indices (figure 7) shows four clear clusters of phytoplankton group bearing clear connections to the different phases of the monsoon and associated changes in salinity. The most prominent species in cluster I were Trichodesmium thiebautii, Stephanopyxis palmeriana,

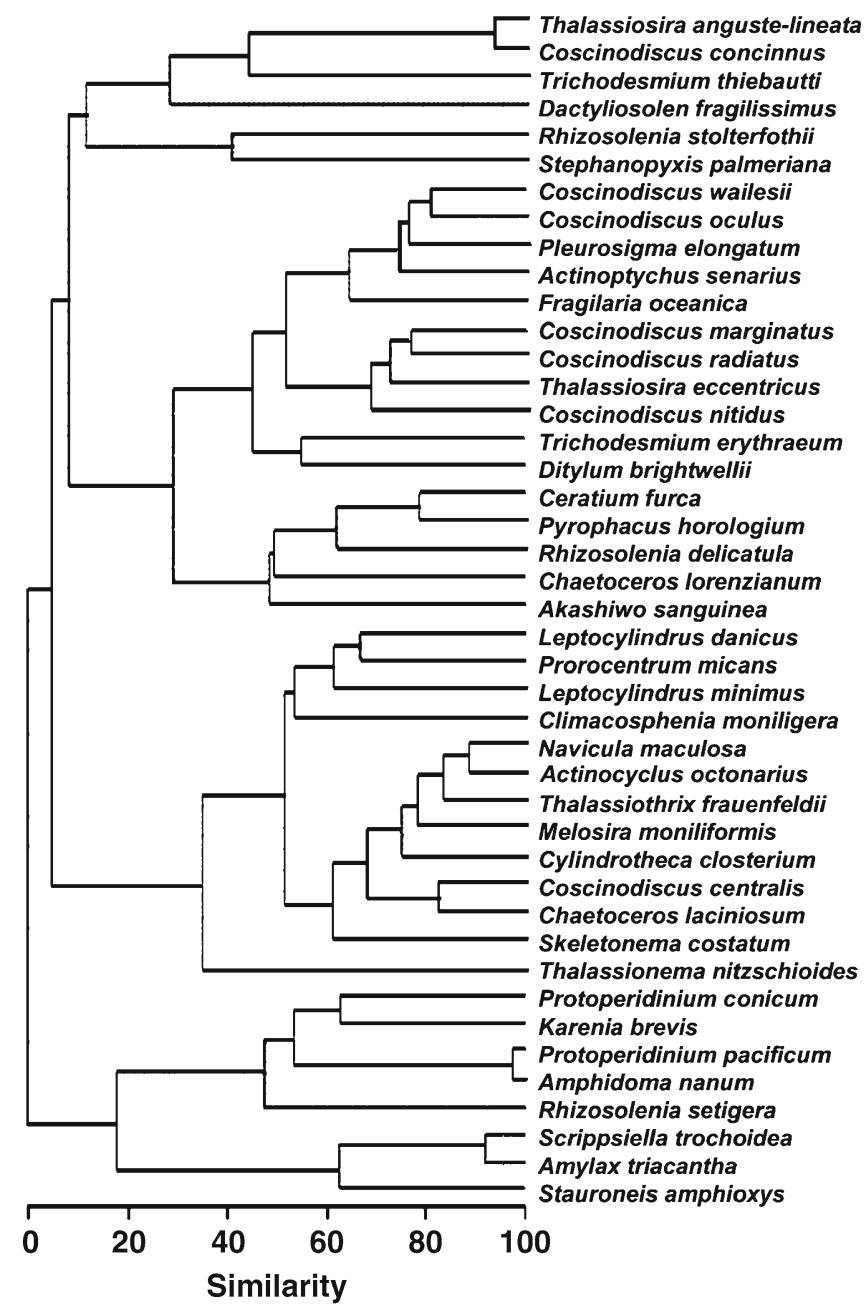

Figure 7. Cluster analysis of dominant phytoplankton species across Monsoon period in Mandovi estuary.
Rhizosolenia stolterforthii, Coscinodiscus concinnus, Thalassiosira anguste-lineata, etc., which were observed during the PreM period when salinity was around $37 \pm 2$ psu. Cluster II comprised of species which were present at Intermediate salinities of $>25$ and $<34$ psu. Within this second cluster, there were four subclusters, the first comprising only of diatoms such as the neritic diatom $F$. oceanica, and others such as Pleurosigma elongatum, Coscinodiscus oculus, Coscinodiscus wailesii and Actinoptychus senarius which were predominant during the PreM and present in much lower numbers throughout the year. The second subcluster was made up of centric diatoms comprising of Thalassiosira eccentricus, Coscinodiscus radiatus, Coscinodiscus marginatus and Coscinodiscus nitidus, which contributed to the large Chl $a$ peak during the late InterM when salinity levels in the estuary started dropping to $<30 \mathrm{psu}$. The third subcluster was made up of species like, Chaetoceros lorenzianum, Rhizosolenia delicatula, Pyrophacus horologium, etc., which were present in high numbers during the PostM season when salinity was $\geq 32 \mathrm{psu}$. The fourth subcluster comprising of Ditylum brightwellii and Trichodesmium erythraeum were species observed sporadically during the PreM and InterM when salinity levels were in excess of $30 \mathrm{psu}$.

Cluster III shows species that appeared to be made up largely of euryhaline species, including the species Skeletonema costatum, Thalassiothrix frauenfeldii, Actinocyclus octonarius, etc., which were present throughout the study period. Cluster III was made up of three subclusters, the first comprising of Thalassionema nitzschoides, the second made up of Skeletonema costatum, Thalassiothrix frauenfeldii, Coscinodiscus centralis and Actinocyclus octonarius among other species. The third subcluster within Cluster III comprised of two species of the chain forming diatom Leptocylindrus, Leptocylindrus danicus and Leptocylindrus minimus. Also present within this group were the diatom Climacosphenia moniligera and Prorocentrum micans.

The fourth cluster represents phytoplankton that grew during the PostM period when salinity levels began to rise following cessation of the rainy season. These included dinoflagellate species such as Amylax triacantha, Protoperidinium tristylum, Scrippsiella trochoidea, Karenia brevis, Gyrodinium spirale, Gonyaulax kofoidii, Alexandrium ostenfeldii and some diatom species such as Chaetoceros messanensis, Rhizosolenia setigera, Pinnularia ambigua, Stauroneis amphioxys.

The succession of the major phytoplankton species observed at our study site as the monsoon progressed is summarized in figure 8. Some species like Trichodesmium thiebautii, Coscinodiscus 


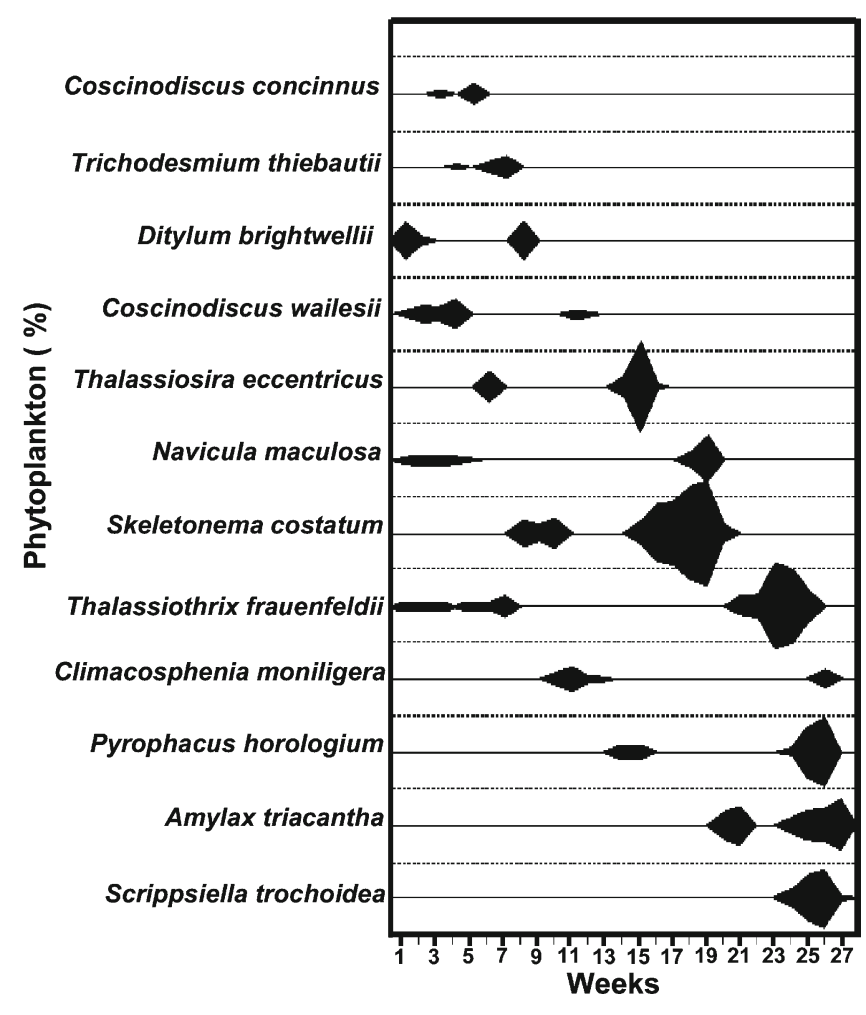

Figure 8. Succession of some major phytoplankton species across Monsoon period in Mandovi estuary.

concinnus, Ditylum brightwellii were present in high numbers from PreM to the InterM. During the monsoon period, Skeletonema costatum, Thalassiosira eccentricus and Navicula maculosa dominated the phytoplankton population. Thalassiothrix frauenfeldii was the dominant species during the early PostM, but was replaced by the dinoflagellates, Amylax triacantha, Scrippsiella trochoidea, etc., during the later part of the PostM.

\section{Discussion}

Present study which was carried out in the Mandovi estuary during the monsoon of 2007 examines lots of changes in the phytoplankton structure with respect to salinity, nitrate and rainfall pattern. This year being the normal monsoonal year (figure 3), where total rainfall can vary between 1500 and $2000 \mathrm{~mm}$ (India Meteorological Department 2007-2008), and where breaks between rainy spells can last for several days at a stretch. Our observations can therefore be considered as baseline data for future studies aimed at understanding the consequences of climatemediated changes in rainfall patterns predicted for the Indian subcontinent (Goswami et al 2006).

There are few studies in the estuaries along the west coast of India that document significant changes in phytoplankton community composition following the onset of the monsoons (Devassy and Goes 1988). One of the limitations of these studies is that they have been based on samples collected monthly. Our daily observations are the first for any tropical estuary from the Indian subcontinent and clearly suggest that monthly observations may not necessarily be representative of the dynamic shifts in phytoplankton populations responding to abrupt shifts in salinity.

During our study, large increase in biomass and cell numbers were observed during the InterM phase, where salinity levels in the estuary dropped to $\sim 30 \mathrm{psu}$ on JD 169 following the first few days of monsoonal showers. The phytoplankton biomass ( $\mathrm{Chl} a>14 \mathrm{mg} \mathrm{m}^{-3}$ ) and counts $(>6 \times$ $10^{4}$ cells $\mathrm{L}^{-1}$ ) recorded during the present study is highest in nature. Two species in particular that appeared to benefit most from this sudden drop in salinity were Thalassiosira eccentricus and Coscinodiscus radiatus (figure 7 ). This response is consistent with previous laboratory and field observations of tropical marine phytoplankton which have shown that in the absence of nutrient limitation, a slight reduction in salinity can significantly enhance growth rates of coastal tropical marine phytoplankton species (Qasim et al 1972; Devassy and Goes 1988), when the estuary begins to freshen following the commencement of rainy season.

Throughout the study period, variations in Chl $a$ were remarkably consistent with cell numbers on a day-to-day basis as evident from the high degree of correlation between these two variables $\left(r^{2}=0.80\right.$, $n=192$ ). This is a noteworthy observation, given that intracellular levels of Chl $a$ can vary among different phytoplanktons depending on cell size and environmental conditions (Bricaud et al 1995).

The chain forming diatom Skeletonema costatum was by far the most dominant during the MoN when the total biomass and cell counts of phytoplankton were at low. Multiple blooms of this organism caused by abrupt swings in salinity were largely responsible for large peaks in phytoplankton biomass during the MoN and the early PostM. During each bloom of Skeletonema costatum, cell counts reached up to $2.4 \times 10^{4}$ cells L $^{-1}$ (figure 6e). No fish mortality was observed during this bloom of Skeletonema costatum due to gill clogging as a result of mucus production Skeletonema costatum as reported by Hallegraeff et al (2003). Skeletonema costatum does seem to be a cosmopolitan organism and has been reported from both temperate and tropical estuaries (Devassy and Goes 1988; Marshall and Alden 1990; Huang et al 2004; Madhu et al 2007; Costa et al 2009). Although Skeletonema costatum is found throughout the year, it appears to be an organism that thrives in brackish (15-18 psu) and highly turbid waters typical 
of the MoN (Prabhu et al 2007; Patil Jagadish and Anil Arga 2008). Other organisms present during the MoN were Thalassiothrix frauenfeldii, Coscinodiscus nitidus and Akashiwo sanguinea. Unlike Skeletonema costatum which appeared to be predisposed to low salinity, both Thalassiothrix frauenfeldii and Coscindodiscus nitidus seemed to tolerate a wider range of salinity and were seen almost throughout the year in moderate numbers and in large numbers during the PostM period.

Another noteworthy finding in this study was the appearance of dinoflagellates in large numbers at the end of the MoN and the beginning of PostM. Ceratium furca and Akashiwo sanguinea were the dominant dinoflagellates during this time. The proportion of dinoflagellate cell numbers relative to diatoms and other phytoplankton was highest during the late MoN and PostM. In general, dinoflagellates are known to grow best in environments that are rich not only in nitrogenous nutrients, but also in humic acid, fulvic acid, and other dissolved organic compounds that constitute the bulk of the coloured dissolved organic matter (CDOM) pool (Prakash and Rashid 1968; Hair and Bassett 1973; Doblin et al 1999). One important source of CDOM is litter from the mangrove laden banks upstream of the Mandovi River. During the MoN, constant flooding and flushing of the mangrove beds causes leaching of CDOM from decaying litter. Another bloom of dinoflagellate Akashiwo sanguinea was also observed around JD 253 with cell numbers reaching $1 \times 10^{4}$ cells $\mathrm{L}^{-1}$. Akashiwo sanguinea has been reported to form toxic red tides and is a species that is generally avoided by zooplankton as well as fish larvae (Fiedler Paul 1982). In the Mandovi estuary, there was no fish mortality associated with this organism, but the appearance of this potentially toxic organism as a dominant component of the phytoplankton community suggests that the Mandovi estuary could be susceptible to outbreaks of this organism if conditions favour more eutrophication.

Major grouping of phytoplankton in the cluster analysis appeared to be largely on the basis of salinity variations during various phases of the monsoon. Euryhaline species like Thalassiothrix fraunfeldii, Navicula maculosa and Melosira moniliformis present throughout the year, by virtue of their ability to tolerate a wide range of salinities, formed a separate cluster (figure 7). The appearance of Trichodesmium thiebautii as well as Trichodesmium erythraeum as coastal neritic species in the estuary suggests an influx of coastal waters into the Mandovi River. There were some species like Climacosphenia moniligera, Navicula maculosa, Ditylum brightwellii, Prorocentrum micans which appeared when the estuary was highly turbid suggesting in all probability their benthic origin. In the PostM phase during which active spells of the rainfall cease, the cluster was dominated by dinoflagellates like Akashiwo sanguinea, Pyrophacus horologium, and Ceratium furca. During this time, flushing was reduced and the estuary slowly started becoming more saline. This also follows the succession pattern of the phytoplankton (figure 8). From the succession pattern it is clearer that the majority of diatoms like Coscinodiscus concinnus, Ditylum brightwellii, Coscinodiscus wailesii, etc., which appeared during PreM, InterM, and MoN phases were later replaced by dinoflagellates like Pyrophacus horologium, Ceratium furca, Amylax triacantha, etc. This study gives us complete knowledge on different types of phytoplankton community adaptation to changing salinity regime in Mandovi estuary across the monsoon period.

The freshening of the estuary due to rainfall and run-off also led to a gradual increase in nitrate concentrations from about 2 to about $8 \mu \mathrm{M}$ at first and then to $>20 \mu \mathrm{M}$ and stabilizing at $2-10 \mu \mathrm{M}$ following the abrupt reduction in salinity (figure 4). Although there are no reports of nitrate or any other nutrients being limiting for phytoplankton in the Mandovi estuary, we hypothesize that both the reduction in salinity and the absence of nutrient limitation, contributed to a surge in phytoplankton cell numbers. This holds good in the present observation that the phytoplankton community of the Mandovi estuary was the most diverse during the MoN when almost fresh water conditions prevailed and also noteworthy is the presence of high turbidity in the water column when their biomass, in terms of Chl $a$ and cell counts of phytoplankton was lowest. This can be compared with the findings of Devassy and Goes (1988) who also found the monsoon was less diverse than PostM. Secchi disk measurements by Pradeep et al (2003) reported that the light penetration in the Mandovi estuary during $\mathrm{MoN}$ is as low as $0.3 \mathrm{~m}$. If this is true for other estuaries along the west coast of India and other tropical estuaries that come under the monsoonal influence, it suggests that a vast majority of tropical estuarine phytoplankton are capable of surviving range of salinity and high turbidity.

In conclusion, the Mandovi estuary is a highly dynamic ecosystem, where phytoplankton communities can change drastically from day-to-day. In general, these observations suggest that monthly or fortnightly sampling may not provide a representative account of phytoplankton diversity and change within tropical estuarine systems that come under the influence of the monsoons. The most important drivers of changes in the phytoplankton community composition within the Mandovi estuary were clearly salinity and nitrate combination. The abrupt decrease in salinity following 
the first monsoonal showers and rapid increase in nitrate concentration was responsible for the increase in phytoplankton biomass observed over our study period. Although our sampling site is not necessarily representative of the entire estuary, it does appear that the Mandovi estuary closer to its mouth is largely a diatom-dominated system for most part of the year, with the exception of a brief period during the PostM, when the increase in salinity and associated changes in the environment appear to favour dinoflagellate growth. During the peak of the MoN, when the estuary was at its freshest, phytoplankton biomass was on the lower side, but surprisingly the community was made up of the largest number of species. Similar observations are also reported from other regions of Donana marshland (SW Spain) and Paraibado Sul river estuary (SE Brazil) by Reys et al (2008) and Costa et al (2009), where species richness is driven by the influence of the freshwater flow in to the estuary. This was due to enhancing the replacement of the species and causing lower phytoplankton biomass. The unusual appearance of Trichodesmium and Fragilaria oceanica within the estuary appeared to be the result of tidal driven influxes of coastal waters into the estuary and did not originate from the estuary studied during present investigation.

\section{Acknowledgements}

We are grateful to Dr S R Shetye, Director, National Institute of Oceanography, Goa for involving us and guiding us during Monsoon Experiments in Mandovi estuary. S Pednekar is thankful to the Director, Space Application Centre, Ahmedabad, for the financial support. This is NIO's contribution number 4990.

\section{References}

Bricaud A, Babin M, Morel A and H Claustre 1995 Variability in the chlorophyll-specific absorption coefficient of natural phytoplankton: Analysis and parametrization; J. Geophys. Res. 100 C7 13,321-13,332.

Clarke K R and Warwick R M 1994 Changes in marine communities: An approach to statistical analysis and interpretation; Plymouth Marine Laboratory, Plymouth.

Costa L S, Huszar V L M and Ovalle A R 2009 Phytoplankton functional groups in a tropical estuary: Hydrological control and nutrient limitation; Estuaries and Coasts 32 508-521.

DeSousa S N, SenGupta R, Sanzgiri S and Rajagopal M D 1981 Studies on nutrients of Mandovi and Zuari river systems; Indian J. Marine Sci. 10 314-321.

Devassy V P and Goes J I 1988 Phytoplankton community structure and succession in tropical estuarine complex; Estuarine Coast. Shelf Sci. 27 671-685.
Doblin M A, Blackburn S I and Halegraeff G M 1999 Growth and biomass stimulation of the toxic dinoflagellate Gymnodinium catenatum (Graham) by dissolved organic substances; J. Exp. Biol. 236 33-47.

Fiedler Paul C 1982 Zooplankton avoidance and reduced grazing responses to Gymnodinium splendens (Dinophyceae); Limnol. Oceanogr. 27(5) 961-965.

Goswami P, Mandal A, Upadhyaya H C and Hourdin F 2006 Advance forecasting of cyclone track over north Indian Ocean using a global circulation model; Mausam 57(1) 111-118.

Hair M E and Bassett C R 1973 Dissolved and particulate humic acids in an east coast estuary; Estuarine Coast. Shelf Sci. 1 107-111.

Hallegraeff G M, Anderson D M and Cembella A D 2003 Manual on harmful marine microalgae; UNESCO Publishing.

Huang L, Jian W, Song X, Huang X, Liu S, Qian P, Yin $\mathrm{K}$ and $\mathrm{Wu}$ M 2004 Species diversity and distribution for phytoplankton of the Pearl River estuary during rainy and dry season; Marine Pollution Bull. 49 588-596.

IMD (India Meteorological Department) 2007-2008 http:// www.imd.gov.in.

Madhu N V, Jyothibabu R, Balachandran K K, Honey U K, Martin G D, Vijay J G, Shiyas C A, Gupta G V M and Achuthankutty C T 2007 Monsoonal impact on planktonic standing stock and abundance in a tropical estuary (Cochin backwaters-India); Estuarine Coast. Shelf Sci. 73 54-64.

Marshall H G and Alden R W 1990 A comparison of phytoplankton assemblages and environmental relationships in three estuarine rivers of the lower Chesapeake Bay; Estuaries 13 287-300.

Parab S G, Matondkar S G P, Gomes H and Goes J I 2006 Monsoon driven changes in phytoplankton populations in the eastern Arabian Sea as revealed by microscopy and HPLC pigment analysis; Cont. Shelf Res. 26(20) 2538-2558.

Parsons T R and Strickland J D H 1963 Discussion of spectrophotometric determination of marine plant pigments, with revised equations for ascertaining chlorophylls and carotenoids; J. Marine Res. 21 155-163.

Patil Jagadish S and Anil Arga C 2008 Temporal variation of diatom benthic propagules in a monsoon-influenced tropical estuary; Cont. Shelf Res. 28(17) 2404-2416.

Prabhu Matondkar S G, Gomes H D, Parab S G, Pednekar S and Goes J I 2007 Phytoplankton diversity, biomass and production; In: The Mandovi and Zuari Estuaries (eds) Shetye S R, Kumar D and Shankar D, National Institute of Oceanography, Dona-Paula, Goa, pp. 139.

Pradeep Ram A S, Shanta N and Chandramohan D 2003 Seasonal shift in net ecosystem production in a tropical estuary. Limnol. Oceanogr. 48(4) 1601-1607.

Prakash A and Rashid M A 1968 Influence of humic substances on the growth of marine phytoplankton: Dinoflagellates; Limnol. Oceanogr. 13 598-606.

Qasim S Z, Bhattathiri P M A and Devassy V P 1972 The influence of salinity on the rate of photosynthesis and abundance of some tropical phytoplankton; Marine Biol. 12 200-206.

Reys I, Casco M A, Toja J and Serrano L 2008 Hydrological complexity supports high phytoplankton richness in the Doñana marshland (SW Spain); Hydrobiologia 614 47-54.

Shannon C E and Weaver W 1963 The mathematical theory of communication; University of Illinois Press, Urbana.

Shetye S R, Shankar D, Neetu S, Suprit K, Michael G S and Chandramohan P 2007 The environment that conditions 
the Mandovi and Zuari estuaries; In: The Mandovi and Zuari Estuaries (eds) Shetye S R, Kumar D and Shankar D, National Institute of Oceanography, Dona-Paula, Goa, pp. 3.

Sundar D and Shetye S R 2005 Tides in the Mandovi and Zuari estuaries, Goa, west coast of India; J. Earth Syst. Sci. 114(5) 493-503.

Suprit K and Shankar D 2008 Resolving orographic rainfall on the Indian west coast; Int. J. Climatol. 28(5) 643657.
Tomas C R 1997 Identifying Marine Phytoplankton (New York: Academic Press), pp. 858.

Vijith V, Sundar D and Shetye S R 2009 Time-dependence of salinity in monsoonal estuaries; Estuarine Coast. Shelf Sci. 85(4) 601-608.

Wright SW, Jeffrey S W, Mantoura R G C, Llewellyn C A, Bjornland D and Welschmeyer N 1991 Improved HPLC method for the analysis of chlorophylls and carotenoids from marine phytoplankton; Marine Ecology Progress Series 77 183-196.

MS received 23 June 2010; revised 24 January 2011; accepted 25 January 2011 